\title{
Body composition changes and its association with dyslipidemia in patients receiving hemodialysis
}

\author{
Priyadarsini Samanta, Debdattaa Bhattacharyya, Ansuman Panigrahi *, Soumya Mishra, \\ Jayanti Mishra, Laxman Kumar Senapati \\ Kalinga Institute of Medical Sciences, KIIT University, Bhubaneswar, 751024, Odisha, India
}

\section{A R T I C L E I N F O}

\section{Keywords:}

Bioelectrical impedance

Blood lipid

Body composition

Chronic kidney disease

Hemodialysis

\begin{abstract}
A B S T R A C T
Problem considered: The study aimed to assess the body composition changes after dialysis in chronic kidney disease (CKD) patients undergoing hemodialysis and to determine the strengths of relationships between various body composition parameters and blood lipid levels in these patients.

Methods: The cross-sectional study was conducted during May-September 2019 involving 97 patients (58 males and 39 females, age: 40-70 years) of CKD undergoing maintenance hemodialysis. The multifrequency bioelectrical impedance analyzer was used to measure various body composition parameters like body fat percent, lean mass percent, body mass index, body fat mass index, fat-free mass index, total body water percent, extracellular water percent, intracellular water percent, nutrition index, prediction marker, basal metabolic rate, and estimated average energy requirement. Blood lipid levels were collected from the patients' clinical records.

Results: All the body composition parameters except nutrition index and prediction marker differed significantly before and after dialysis. Various body composition parameters were significantly correlated with one or more lipid levels before and after dialysis.

Conclusion: The body composition parameters change significantly after hemodialysis among CKD patients. Our findings suggest that body composition parameters, whether measured before or after dialysis could be useful in assessing dyslipidemia in patients receiving hemodialysis.
\end{abstract}

\section{Introduction}

Chronic kidney disease (CKD) is described as a gradual loss of kidney function over months or years. ${ }^{1}$ Globally, around 753 million people were affected by CKD in the year $2016 .^{2}$ The incidence of obesity-related glomerulonephropathy has been steadily increasing in patients with CKD. ${ }^{3}$ In an earlier study, it has been reported that the relative risks for CKD in overweight and obese individuals as compared to individuals with normal BMI are 1.40 and 1.83 respectively. ${ }^{4}$ The independent risk ratio for CKD in patients with metabolic syndrome is 1.86 as shown in another study. ${ }^{5}$ Therefore, it is important to educate patients with renal disease regarding obesity prevention especially during the early stages of renal disease. Once hemodialysis is initiated in these patients, it becomes necessary to address the cardiovascular risk factors to reduce the overall risk of mortality among these patients. ${ }^{6}$ Currently, various methods such as dual-energy $\mathrm{x}$-ray absorptiometry, computed tomography, magnetic resonance imaging, underwater weighing method, and bio-electrical impedance analysis (BIA) are available for estimation of body composition parameters including percent body fat. Although BIA does not provide information on body fat distribution, it is a cost-effective, rapid and a non-invasive procedure which has been widely used as a useful tool for estimating body composition parameters in hemodialysis subjects. ${ }^{7-10}$ It has the advantage of low inter-observer error as it is highly reproducible. ${ }^{11}$

In BIA, a low electrical current is introduced into the body. Lean tissue which consists of essentially of electrolyte-containing water, conducts the electrical current, while fat tissue with low water content acts as an insulator. The impedance of the body is therefore determined mainly by the low-impedance lean tissues and the amount of body water plays an important role in the bio-electrical impedance analysis. The amount of body water changes significantly before and after dialysis in CKD patients as excess body water is removed through dialysis. The

\footnotetext{
* Corresponding author. Community Medicine Kalinga Institute of Medical Sciences, KIIT University, Bhubaneswar, 751024, Odisha, India.

E-mail addresses: dr.priyasamanta@gmail.com (P. Samanta), debdattaabhattacharyya@gmail.com (D. Bhattacharyya), dr.ansuman3@gmail.com (A. Panigrahi), soumya.mishra@kims.ac.in (S. Mishra), jayantimishra31@gmail.com (J. Mishra), meet.laxmans1@gmail.com (L. Kumar Senapati).
} 
amount of percent body fat estimated by BIA in patients with renal failure undergoing dialysis might differ from the true values due to retention of atypical amounts of water in these patients. Thus, the question arises whether body composition parameters measured before or after dialysis should be used in health assessment of patients receiving hemodialysis.

There is limited research regarding the validity of body composition parameters in assessing the health of patients receiving hemodialysis. ${ }^{6}$ The present study aimed to assess the changes in body composition parameters after dialysis in CKD patients undergoing hemodialysis and determine the strengths of the relationship between various body composition parameters and blood lipid levels in these patients.

\section{Methods}

This cross-sectional study was conducted from May to September 2019 in patients of chronic kidney disease undergoing maintenance hemodialysis. Assuming the percent change in body fat percentage postdialysis as $19.6 \%$ based on the findings of an earlier study ${ }^{6}$ with $8.5 \%$ acceptable margin of error, design effect 1.0, and 95\% level of significance, the sample size was estimated as 84 . All CKD patients consecutively attending the nephrology clinic at Pradyumna Bal Memorial Hospital were considered for the study. The CKD patients in the age range of 40-60 years, who had $4 \mathrm{~h}$ of hemodialysis sessions 3 times per week for a period of a minimum of 1 year were considered for inclusion in the study. Pregnant or lactating women, patients having carcinoma, acute or chronic infection, severe cardiac, pulmonary, or hepatic failures were excluded from the study. Patients with implanted defibrillators, and cardiac pacemakers were also not included in the study. Besides, patients who were unstable or undergoing medications affecting their metabolic rate; those who underwent extremity amputation, and who had metal prosthesis or artificial joints were excluded. Overall, 103 eligible patients were approached for the study, four of them denied to participate and data obtained from two patients were inadequate. Finally, data of 97 patients were considered for statistical analysis.

Before the commencement of the study, the research protocol was explained to all the study participants who subsequently provided written informed consent. They were also informed that they were free to participate or withdraw from the study at any point of time and utmost privacy and confidentiality would be maintained regarding the information obtained for the study. The research protocol was approved by the Institutional Ethics Committee of the authors' institution (Ref. No: KIIT/KIMS/IEC/28/2019; Date: April 30, 2019).

We used a structured schedule to collect all relevant information. Anthropometric measurements such as height, weight, waist circumference, hip circumference were measured following standard techniques. Body mass index (BMI) was obtained by body weight $(\mathrm{kg})$ divided by squared body height $\left(\mathrm{m}^{2}\right)$. The Multifrequency bioelectrical impedance analyzer [Body Stat, Quad Scan 4000] was used to measure the following body composition parameters: body fat content, lean mass/fat-free mass, body fat mass index (BFMI), fat-free mass index (FFMI), body water content [total body water (TBW), extracellular water (ECW), intracellular water (ICW)], nutrition index (ECW/TBW), basal metabolic rate (BMR), and illness prediction marker. The basal metabolic rate is the estimated minimum energy requirement of the body at rest. The prediction marker or impedance ratio is the ratio between the impedance measurement at $200 \mathrm{kHz}$ and $5 \mathrm{kHz}$ and this value is always less than 1.00. The higher values of the illness prediction marker and nutrition index indicate that the body cells are less healthy. The blood lipid profile included high-density lipoprotein cholesterol (HDL-C), low-density lipoprotein (LDL-C), triglyceride (TG), and total cholesterol (TC) which were obtained from the patients' clinical records. The participants were interviewed to record their physical activities during the last $24 \mathrm{~h}$. Based on the type and intensity of these activities, levels of physical activity were calculated for each of the participants. Then the activity level was used in the estimation of the activity energy requirement which is known as estimated average energy requirement (EAR).

All the measurements were performed on the same day after the patient had fasted for $12 \mathrm{~h}$ and within $30 \mathrm{~min}$ after termination of the hemodialysis period. Bioimpedance spectroscopy was performed in standardized conditions i.e. a quiet environment, an ambient temperature of $22{ }^{\circ} \mathrm{C}-24^{\circ} \mathrm{C}$, after voiding, and after being $20 \mathrm{~min}$ at rest in the supine position. ${ }^{5,12}$

Normality of data was evaluated using Shapiro-Wilk test. The body composition parameters before and after dialysis were compared using paired $t$-test as the parameters were normally distributed. The demographic and lipid profile of the male and female participants were compared using unpaired $t$-test. Pearson correlation coefficients were calculated to determine the strength of the linear relationships between body composition parameters and blood lipid levels. All statistical analyses were performed using SPSS version 21.0 software; data were expressed as mean $\pm \mathrm{SD}$ and the significance level was set at $\mathrm{p}<0.05$.

\section{Results}

Table 1 presents the gender-wise distribution of baseline characteristics of the study participants. The distribution of age, BMI, HDL-C, LDLC, TC, and TG was similar between the male $(\mathrm{n}=58)$ and female $(\mathrm{n}=$ 39) participants. Table 2 depicts the changes in body composition parameters before and after dialysis. All the parameters differed significantly except nutrition index in both males and females and prediction marker in females.

Table 3 shows the relationships between various body composition parameters and blood lipid levels before and after dialysis in male participants. Body fat $\%$ and Lean mass $\%$ were found to be significantly correlated with HDL-C, LDL-C, and TC levels before and after dialysis. BFMI was significantly correlated with HDL-C, LDL-C, and TC level before dialysis and with LDL-C and TC after dialysis. Concerning physical activity, BMR per kg body weight and EAR per kg body weight were significantly correlated with HDL-C before dialysis whereas post-dialysis values were correlated with HDL-C, LDL-C, and TC level.

Table 4 reveals that in female participants, various body composition parameters such as body fat $\%$, lean mass $\%$, dry lean mass $\%$, ECW\%, ICW\%, and BFMI were significantly correlated with one or more lipid levels before and after dialysis. Concerning physical activity, the correlation coefficients of BMR per $\mathrm{kg}$ body weight and EAR per kg body weight with HDL-C, LDL-C, and TC were significant before and after dialysis.

\section{Discussion}

Most of the parameters provided by BIA are estimated by the impedance associated with the amount of body water ${ }^{13,14}$ and thus the pre and post-HD changes in the parameters are expected and must be considered while interpreting the BIA results in HD subjects. These

Table 1

Baseline characteristics of the study participants $(n=97)$.

\begin{tabular}{|c|c|c|c|}
\hline \multirow[t]{2}{*}{ Variable } & \multirow{2}{*}{$\frac{\text { Male }(\mathrm{n}=58)}{(\text { Mean } \pm S D)}$} & \multirow{2}{*}{$\frac{\text { Female }(\mathrm{n}=39)}{(\text { Mean } \pm \mathrm{SD})}$} & \multirow[t]{2}{*}{$\mathrm{p}^{*}$} \\
\hline & & & \\
\hline Age (year) & $53.39 \pm 6.35$ & $51.69 \pm 6.51$ & 0.203 \\
\hline Height $(\mathrm{cm})$ & $166.39 \pm 5.18$ & $153.77 \pm 4.89$ & 0.000 \\
\hline Weight (kg) & $65.01 \pm 10.85$ & $53.53 \pm 10.71$ & 0.000 \\
\hline Waist/hip ratio & $1.02 \pm 0.03$ & $0.99 \pm 0.03$ & 0.005 \\
\hline BMR (Kcal) & $1589.36 \pm 217.07$ & $1281.95 \pm 117.24$ & 0.000 \\
\hline BMI $\left(\mathrm{kg} / \mathrm{m}^{2}\right)$ & $23.48 \pm 3.76$ & $22.66 \pm 4.58$ & 0.338 \\
\hline HDL (mg/dl) & $42.17 \pm 11.63$ & $43.72 \pm 13.32$ & 0.547 \\
\hline LDL (mg/dl) & $159.39 \pm 37.57$ & $152.33 \pm 29.18$ & 0.325 \\
\hline Total cholesterol (mg/dl) & $241.12 \pm 40.54$ & $237.03 \pm 37.54$ & 0.617 \\
\hline Triglyceride $(\mathrm{mg} / \mathrm{dl})$ & $193.97 \pm 75.69$ & $203.95 \pm 77.50$ & 0.530 \\
\hline
\end{tabular}

*p $<0.05$ statistically significant. 
Table 2

Changes in body composition parameters before and after dialysis in chronic kidney disease patients undergoing hemodialysis $(n=97)$.

\begin{tabular}{|c|c|c|c|c|c|c|}
\hline \multirow[t]{3}{*}{ Variable } & \multicolumn{2}{|c|}{ Males $(\mathrm{n}=58)$} & \multirow[t]{3}{*}{$\mathbf{p}$} & \multicolumn{2}{|c|}{ Females $(\mathrm{n}=39)$} & \multirow[t]{3}{*}{$\mathrm{p}$} \\
\hline & $\begin{array}{l}\text { Pre- } \\
\text { dialysis }\end{array}$ & $\begin{array}{l}\text { Post- } \\
\text { dialysis }\end{array}$ & & $\begin{array}{l}\text { Pre- } \\
\text { dialysis }\end{array}$ & $\begin{array}{l}\text { Post- } \\
\text { dialysis }\end{array}$ & \\
\hline & $\begin{array}{l}\text { (Mean } \\
\pm \text { SD) }\end{array}$ & $\begin{array}{l}\text { (Mean } \\
\pm \text { SD) }\end{array}$ & & $\begin{array}{l}\text { (Mean } \\
\pm \text { SD) }\end{array}$ & $\begin{array}{l}\text { (Mean } \\
\pm \text { SD) }\end{array}$ & \\
\hline $\begin{array}{l}\text { Body } \\
\text { weight } \\
\text { (kg) }\end{array}$ & $\begin{array}{l}65.01 \pm \\
10.84\end{array}$ & $\begin{array}{l}63.37 \pm \\
10.82\end{array}$ & 0.00 & $\begin{array}{l}53.53 \pm \\
10.71\end{array}$ & $\begin{array}{l}51.83 \pm \\
10.55\end{array}$ & 0.00 \\
\hline Body fat $\%$ & $\begin{array}{l}18.27 \pm \\
6.2\end{array}$ & $\begin{array}{l}22.89 \pm \\
6.38\end{array}$ & 0.00 & $\begin{array}{l}28.30 \pm \\
8.97\end{array}$ & $\begin{array}{l}33.08 \pm \\
8.62\end{array}$ & 0.00 \\
\hline Lean mass $\%$ & $\begin{array}{l}81.73 \pm \\
6.19\end{array}$ & $\begin{array}{l}77.66 \pm \\
6.74\end{array}$ & 0.00 & $\begin{array}{l}71.86 \pm \\
9.21\end{array}$ & $\begin{array}{l}66.37 \pm \\
10.34\end{array}$ & 0.00 \\
\hline $\begin{array}{l}\text { Dry lean } \\
\text { mass } \%\end{array}$ & $\begin{array}{l}14.88 \pm \\
5.50\end{array}$ & $\begin{array}{l}15.26 \pm \\
5.65\end{array}$ & 0.00 & $\begin{array}{l}11.16 \pm \\
3.62\end{array}$ & $\begin{array}{l}10.21 \pm \\
4.04\end{array}$ & 0.00 \\
\hline TBW\% & $\begin{array}{l}66.86 \pm \\
8.60\end{array}$ & $\begin{array}{l}62.23 \pm \\
8.41\end{array}$ & 0.00 & $\begin{array}{l}60.70 \pm \\
10.01\end{array}$ & $\begin{array}{l}56.69 \pm \\
9.72\end{array}$ & 0.00 \\
\hline ECW\% & $\begin{array}{l}29.01 \pm \\
4.21\end{array}$ & $\begin{array}{l}27.24 \pm \\
4.38\end{array}$ & 0.00 & $\begin{array}{l}28.72 \pm \\
4.44\end{array}$ & $\begin{array}{l}27.14 \pm \\
4.45\end{array}$ & 0.00 \\
\hline ICW\% & $\begin{array}{l}34.52 \pm \\
3.83\end{array}$ & $\begin{array}{l}33.09 \pm \\
3.66\end{array}$ & 0.001 & $\begin{array}{l}29.12 \pm \\
3.96\end{array}$ & $\begin{array}{l}27.39 \pm \\
4.13\end{array}$ & 0.005 \\
\hline $\begin{array}{l}\text { Nutrition } \\
\text { index }\end{array}$ & $\begin{array}{l}0.46 \pm \\
0.039\end{array}$ & $\begin{array}{l}0.45 \pm \\
0.038\end{array}$ & 0.184 & $\begin{array}{l}0.49 \pm \\
0.03\end{array}$ & $\begin{array}{l}0.49 \pm \\
0.03\end{array}$ & 0.659 \\
\hline $\begin{array}{c}\text { Prediction } \\
\text { marker }\end{array}$ & $\begin{array}{l}0.85 \pm \\
0.07\end{array}$ & $\begin{array}{l}0.82 \pm \\
0.07\end{array}$ & 0.00 & $\begin{array}{l}0.86 \pm \\
0.07\end{array}$ & $\begin{array}{l}0.84 \pm \\
0.05\end{array}$ & 0.278 \\
\hline $\mathrm{BMR} / \mathrm{kg}$ & $\begin{array}{l}24.78 \pm \\
2.13\end{array}$ & $\begin{array}{l}23.53 \pm \\
1.85\end{array}$ & 0.00 & $\begin{array}{l}24.58 \pm \\
3.94\end{array}$ & $\begin{array}{l}23.69 \pm \\
3.67\end{array}$ & 0.00 \\
\hline $\mathrm{EAR} / \mathrm{kg}$ & $\begin{array}{l}37.68 \pm \\
3.54\end{array}$ & $\begin{array}{l}36.54 \pm \\
3.28\end{array}$ & 0.00 & $\begin{array}{l}38.04 \pm \\
6.58\end{array}$ & $\begin{array}{l}36.91 \pm \\
6.13\end{array}$ & 0.00 \\
\hline $\begin{array}{l}\text { BMI (kg/ } \\
\left.\mathrm{m}^{2}\right)\end{array}$ & $\begin{array}{l}23.48 \pm \\
3.76\end{array}$ & $\begin{array}{l}23.03 \pm \\
3.77\end{array}$ & 0.00 & $\begin{array}{l}22.66 \pm \\
4.58\end{array}$ & $\begin{array}{l}22.09 \pm \\
4.49\end{array}$ & 0.00 \\
\hline $\begin{array}{l}\text { BFMI (kg/ } \\
\left.\mathrm{m}^{2}\right)\end{array}$ & $\begin{array}{l}4.39 \pm \\
1.96\end{array}$ & $\begin{array}{l}5.34 \pm \\
1.97\end{array}$ & 0.00 & $\begin{array}{l}6.70 \pm \\
3.29\end{array}$ & $\begin{array}{l}7.58 \pm \\
3.27\end{array}$ & 0.00 \\
\hline $\begin{array}{l}\text { FFMI }(\mathrm{kg} / \\
\left.\mathrm{m}^{2}\right)\end{array}$ & $\begin{array}{l}19.09 \pm \\
2.73\end{array}$ & $\begin{array}{l}17.69 \pm \\
2.85\end{array}$ & 0.00 & $\begin{array}{l}15.95 \pm \\
1.86\end{array}$ & $\begin{array}{l}14.50 \pm \\
2.02\end{array}$ & 0.00 \\
\hline
\end{tabular}

Note:SD: Standard deviation; TBW: Total body water; ECW: Extracellular water; ICW: Intracellular water; BMR: Basal metabolic rate; EAR: Estimated average energy requirement; BMI: Body mass index; BFMI: Body fat mass index; FFMI: Fat-free mass index; $\mathrm{p}<0.05$ statistically significant.

parameters have not yet been precisely investigated to date. In this study, we assessed the changes in the body composition parameters before and after hemodialysis in CKD subjects and analyzed the relationships of various body composition parameters with blood lipid levels. We found higher body fat $\%$ and BFMI after dialysis than before dialysis in both sexes and higher dry lean mass $\%$ in males while all other parameters had lower values after dialysis. Noguchi et al. also observed higher body fat $\%$ and a lower skeletal muscle $\%$ after dialysis as compared to before dialysis in their study. ${ }^{6}$ In another study conducted in two hospitals of Seoul, the post-HD value of body fat $\%$ was higher than the pre-HD value of $\mathrm{BF} \%$ whereas, in the case of other parameters, the pre-HD values were higher. ${ }^{15}$ Similar results have also been reported in other studies. ${ }^{16,17}$ These changes can be attributed to the changes in the amount of body water. Based on the subjective assessment of the patients' average activity level for $24 \mathrm{~h}$, we estimated the total daily energy expenditure level using the BIA. There was a significant decline in the basal metabolic rate $(\mathrm{Kcal} / \mathrm{kg})$ and the estimated average energy requirement $(\mathrm{Kcal} / \mathrm{kg})$ after dialysis. The reduction in values of nutrition index and prediction marker after dialysis indicates that the health or nutritional status of the body cells improves after dialysis although the change is not statistically significant.

Our analyses revealed significant correlations between body composition parameters and blood lipid levels. In male or female CKD patients the body composition parameters such as body fat $\%$ and BFMI were positively correlated and lean mass $\%$ was negatively correlated with HDL-C, LDL-C, and TC. No major differences were observed in the strengths of the relationships between body composition parameters before and after dialysis, and the blood lipid levels. Similar observations
Table 3

Relationship between various body composition parameters and blood lipid levels in male patients with CKD $(\mathrm{n}=58)$.

\begin{tabular}{|c|c|c|c|c|}
\hline \multirow[t]{2}{*}{ Variables } & $\mathrm{HDL}-\mathrm{C}$ & LDL - C & $\mathrm{TC}$ & TG \\
\hline & $(\mathrm{mg} / \mathrm{dl})$ & $(\mathrm{mg} / \mathrm{dl})$ & $(\mathrm{mg} / \mathrm{dl})$ & $(\mathrm{mg} / \mathrm{dl})$ \\
\hline \multicolumn{5}{|l|}{ Pre-dialysis } \\
\hline Body weight & -0.022 & 0.131 & 0.176 & 0.115 \\
\hline Body fat $\%$ & $-0.364^{* *}$ & $0.314^{*}$ & $0.348^{* *}$ & 0.071 \\
\hline Lean mass $\%$ & $0.364^{* *}$ & $-0.314^{*}$ & $-0.348^{* *}$ & -0.071 \\
\hline Dry lean mass\% & 0.233 & -0.086 & 0.016 & -0.035 \\
\hline TBW\% & 0.114 & -0.171 & -0.262 & -0.030 \\
\hline ECW\% & 0.024 & -0.178 & -0.205 & 0.055 \\
\hline ICW\% & 0.162 & -0.087 & -0.218 & -0.131 \\
\hline Nutrition index & -0.126 & -0.076 & -0.004 & 0.187 \\
\hline Prediction marker & 0.034 & -0.266 & -0.245 & -0.203 \\
\hline $\mathrm{BMR} / \mathrm{kgbw}$ & $0.314^{*}$ & -0.253 & -0.239 & 0.011 \\
\hline $\mathrm{EAR} / \mathrm{kgbw}$ & $0.392^{* *}$ & -0.162 & -0.161 & -0.088 \\
\hline BMI & 0.006 & 0.187 & 0.177 & 0.007 \\
\hline BFMI & $-0.288^{*}$ & $0.330^{*}$ & $0.351 * *$ & 0.048 \\
\hline FFMI & 0.215 & 0.021 & -0.008 & -0.026 \\
\hline \multicolumn{5}{|l|}{ Post dialysis } \\
\hline Body weight & -0.029 & 0.141 & 0.189 & 0.124 \\
\hline Body fat $\%$ & $-0.315^{*}$ & $0.311^{*}$ & $0.377^{* *}$ & 0.018 \\
\hline Lean mass $\%$ & $0.294^{*}$ & $-0.290^{*}$ & $-0.350 * *$ & 0.015 \\
\hline Dry lean mass $\%$ & 0.237 & -0.090 & 0.010 & -0.039 \\
\hline TBW\% & 0.077 & -0.193 & $-0.318^{*}$ & -0.002 \\
\hline ECW\% & 0.110 & -0.251 & $-0.363^{* *}$ & -0.113 \\
\hline ICW\% & 0.011 & -0.085 & -0.165 & 0.115 \\
\hline Nutrition index & 0.029 & -0.191 & $-0.267^{*}$ & -0.159 \\
\hline Prediction marker & 0.084 & $-0.276^{*}$ & $-0.283^{*}$ & -0.197 \\
\hline $\mathrm{BMR} / \mathrm{kgbw}$ & $0.314^{*}$ & $-0.344^{* *}$ & $-0.408^{* *}$ & -0.082 \\
\hline EAR/kgbw & $0.332^{*}$ & $-0.273^{*}$ & $-0.317^{*}$ & -0.061 \\
\hline BMI & -0.002 & 0.196 & 0.193 & 0.031 \\
\hline BFMI & -0.249 & $0.335^{*}$ & $0.386^{* *}$ & 0.015 \\
\hline FFMI & 0.171 & 0.028 & -0.012 & 0.030 \\
\hline
\end{tabular}

HDL-C: High-density lipoprotein-Cholesterol; LDL-C: Low-density lipoproteinCholesterol; TC: Total cholesterol; TG: Triglyceride; Total body water; ECW: Extracellular water; ICW: Intracellular water; BMR: Basal metabolic rate; EAR: Estimated average energy requirement; BMI: Body mass index; BFMI: Body fat mass index; FFMI: Fat-free mass index; *Statistically significant at $\mathrm{p}<0.05$; $* *$ Statistically significant at $\mathrm{p}<0.01$.

were reported by Noguchi et al. who showed strong correlations between body fat $\%$ and skeletal muscle mass $\%$ with blood lipid levels. ${ }^{6}$ In another study, Kobayashi et al. reported that the body fat $\%$ estimated by BIA was useful for the prediction of TC, LDL-C, and TG levels in Japanese men. ${ }^{7}$ This suggests that body composition parameters including body fat $\%$, lean mass $\%$, and BFMI whether measured before or after dialysis has relevance in the context of health assessment of patients receiving hemodialysis. Concerning the physical activity level, our study supports the view that there are strong correlations between BMR $/ \mathrm{kg}$ and EAR $/ \mathrm{kg}$ with blood lipid levels. With the increase in activity level among the CKD patients, HDL-C level decreases and levels of LDL-C, TC increase. It can be suggested that the measurement of daily energy expenditure levels might be useful in determining the health status of patients receiving hemodialysis.

There are a few limitations of the study. This was a single-center study and focused on subjects with a narrow age range and thus the result might not be the true representative of patients receiving hemodialysis from a wider geographic region or wider age range. However, focusing on patients with a specific age group minimized the confounding effect of age on the relationship of the body composition parameters and blood lipid levels. Another limitation of the study is that there might be an introduction of reporting bias while doing the subjective assessment of the activity level among the patients. Furthermore, as our study was a cross-sectional study, further large-scale longitudinal studies should be performed to confirm the findings of our study. 
Table 4

Relationship between various body composition parameters and blood lipid levels in female patients with CKD $(\mathrm{n}=39)$.

\begin{tabular}{|c|c|c|c|c|}
\hline \multirow[t]{2}{*}{ Variables } & \multirow{2}{*}{$\frac{\mathrm{HDL}-\mathrm{C}}{(\mathrm{mg} / \mathrm{dl})}$} & \multirow{2}{*}{$\frac{\mathrm{LDL}-\mathrm{C}}{(\mathrm{mg} / \mathrm{dl})}$} & \multirow{2}{*}{$\frac{\mathrm{TC}}{(\mathrm{mg} / \mathrm{dl})}$} & \multirow{2}{*}{$\frac{\mathrm{TG}}{(\mathrm{mg} / \mathrm{dl})}$} \\
\hline & & & & \\
\hline \multicolumn{5}{|l|}{ Pre-dialysis } \\
\hline Body weight & -0.219 & $0.374^{*}$ & 0.309 & 0.029 \\
\hline Body fat $\%$ & $-0.381^{*}$ & $0.492 * *$ & $0.404 *$ & 0.209 \\
\hline Lean mass \% & $0.365^{*}$ & $-0.479 * *$ & $-0.377^{*}$ & -0.177 \\
\hline Dry lean mass $\%$ & $0.321 *$ & -0.086 & 0.028 & $-0.337^{\prime}$ \\
\hline TBW\% & 0.219 & $-0.409^{*}$ & $-0.357^{*}$ & -0.041 \\
\hline ECW\% & 0.238 & $-0.390^{*}$ & -0.315 & -0.017 \\
\hline ICW\% & 0.112 & $-0.359 *$ & $-0.405^{*}$ & -0.126 \\
\hline Nutrition index & 0.210 & -0.151 & 0.007 & 0.100 \\
\hline Prediction marker & 0.105 & 0.020 & 0.151 & 0.141 \\
\hline BMR/kgbw & $0.359 *$ & $-0.448^{* *}$ & $-0.321 *$ & -0.106 \\
\hline $\mathrm{EAR} / \mathrm{kgbw}$ & $0.403^{*}$ & $-0.427 * *$ & -0.283 & -0.113 \\
\hline BMI & -0.241 & $0.346^{*}$ & 0.294 & 0.004 \\
\hline BFMI & $-0.329 *$ & $0.430 * *$ & $0.338^{*}$ & 0.109 \\
\hline FFMI & -0.011 & 0.091 & 0.126 & -0.184 \\
\hline \multicolumn{5}{|l|}{ Post dialysis } \\
\hline Body weight & -0.220 & $0.378^{*}$ & 0.314 & 0.035 \\
\hline Body fat $\%$ & $-0.354^{*}$ & $0.421 * *$ & $0.385^{*}$ & 0.220 \\
\hline Lean mass $\%$ & 0.178 & -0.232 & -0.313 & -0.110 \\
\hline Dry lean mass $\%$ & 0.270 & -0.008 & 0.089 & -0.283 \\
\hline TBW\% & 0.209 & $-0.370^{*}$ & $-0.386^{*}$ & -0.092 \\
\hline ECW\% & 0.148 & -0.286 & -0.315 & -0.084 \\
\hline ICW\% & 0.158 & -0.260 & $-0.361 *$ & -0.068 \\
\hline Nutrition index & -0.051 & 0.031 & 0.033 & 0.035 \\
\hline Prediction marker & -0.052 & 0.103 & 0.216 & 0.052 \\
\hline BMR/kgbw & $0.364 *$ & $-0.444 * *$ & $-0.357^{*}$ & -0.151 \\
\hline $\mathrm{EAR} / \mathrm{kgbw}$ & $0.418^{* * *}$ & $-0.419^{* *}$ & -0.299 & -0.135 \\
\hline BMI & -0.244 & $0.359^{*}$ & 0.312 & 0.024 \\
\hline BFMI & $-0.329 *$ & $0.401 *$ & $0.351^{*}$ & 0.135 \\
\hline FFMI & -0.008 & 0.151 & 0.119 & -0.176 \\
\hline
\end{tabular}

HDL-C: High-density lipoprotein-Cholesterol; LDL-C: Low-density lipoproteinCholesterol; TC: Total cholesterol; TG: Triglyceride; Total body water; ECW: Extracellular water; ICW: Intracellular water; BMR: Basal metabolic rate; EAR: Estimated average energy requirement; BMI: Body mass index; BFMI: Body fat mass index; FFMI: Fat-free mass index; *Statistically significant at $\mathrm{p}<0.05$; $* *$ Statistically significant at $\mathrm{p}<0.01$.

\section{Conclusion}

The study has shown that almost all the body composition parameters change significantly after hemodialysis among CKD patients. Various body composition parameters were significantly correlated with one or more lipid levels before and after hemodialysis. The study findings indicate that the body composition parameters whether measured before or after hemodialysis could be useful in the assessment of dyslipidemia in patients receiving hemodialysis.

\section{Source of funding}

None.

\section{Declaration of competing interest}

All the authors hereby declare that they have no conflicts of interest.

\section{References}

1 International Society of Nephrology and International Federation of Kidney Foundations. Chrinic kidney disease. https://www.worldkidneyday.org/facts/chron ic-kidney-disease/; 2019. Accessed October 25, 2019. Published.

2 Bikbov B, Perico N, Remuzzi G. Disparities in chronic kidney disease prevalence among males and females in 195 countries: analysis of the global burden of disease 2016 study. Nephron. 2018;139(4):313-318. https://doi.org/10.1159/000489897.

3 Ingsathit A, Thakkinstian A, Chaiprasert A, et al. Prevalence and risk factors of chronic kidney disease in the Thai adult population: Thai SEEK study. Nephrol Dial Transplant. 2010;25(5):1567-1575. https://doi.org/10.1093/ndt/gfp669.

4 Wang Y, Chen X, Song Y, Caballero B, Cheskin LJ. Association between obesity and kidney disease: a systematic review and meta-analysis. Kidney Int. 2008;73(1):19-33. https://doi.org/10.1038/sj.ki.5002586.

5 Tozawa M, Iseki C, Tokashiki K, et al. Metabolic syndrome and risk of developing chronic kidney disease in Japanese adults. Hypertens Res. 2007;30(10):937-943. https://doi.org/10.1291/hypres.30.937.

6 Noguchi M, Yamaguchi S, Koshino Y, Kimura A, Miyagi S. Validity of body impedance analysis for evaluating body composition in patients undergoing longterm hemodialysis. J Phys Ther Sci. 2015;27(6):1649-1652. https://doi.org/ 10.1589/jpts.27.1649.

7 Kobayashi J, Murano S, Kawamura I, et al. The relationship of percent body fat by bioelectrical impedance analysis with blood pressure, and glucose and lipid parameters. J Atherosclerosis Thromb. 2006;13(5):221-226. https://doi.org/10.5551/ jat.13.221.

8 Castellano S, Palomares I, Molina M, et al. Clinical, analytical and bioimpedance characteristicsof persistently overhydrated haemodialysis patients. Nefrologia. 2014; 34(6):716-723. https://doi.org/10.3265/Nefrologia.pre2014.Sep.12468.

9 Davies SJ, Davenport A. The role of bioimpedance and biomarkers in helping to aid clinical decision-making of volume assessments in dialysis patients. Kidney Int. 2014; 86(3):489-496. https://doi.org/10.1038/ki.2014.207.

10 Keane D, Gardiner C, Lindley E, Lines S, Woodrow G, Wright M. Changes in body composition in the two years after initiation of haemodialysis: a retrospective cohort study. Nutrients. 2016;8(702). https://doi.org/10.3390/nu8110702.

11 Davenport A, Willicombe M. Comparison of fluid status in patients treated by different modalities of peritoneal dialysis using multi-frequency bioimpedance. Int $J$ Artif Organs. 2009;32(11):779-786. https://doi.org/10.1177/ 039139880903201103.

12 Di Iorio BR, Scalfi L, Terracciano V, Bellizzi V. A systematic evaluation of bioelectrical impedance measurement after hemodialysis session. Kidney Int. 2004;65 (6):2435-2440. https://doi.org/10.1111/j.1523-1755.2004.00660.x.

13 Kyle UG, Bosaeus I, De Lorenzo AD, et al. Bioelectrical impedance analysis - Part I: review of principles and methods. Clin Nutr. 2004;23(5):1226-1243. https://doi.org/ 10.1016/j.clnu.2004.06.004.

14 Kotanko P, Levin NW, Zhu F. Current state of bioimpedance technologies in dialysis. Nephrol Dial Transplant. 2008;23(3):808-812. https://doi.org/10.1093/ndt/gfm889.

$15 \mathrm{Kim} \mathrm{H}$, Choi GH, Shim KE, et al. Changes in bioimpedance analysis components before and after hemodialysis. Kidney Res Clin Pract. 2018;37(4):393-403. https:// doi.org/10.23876/j.krcp.18.0035.

16 Bellizzi V, Scalfi L, Terracciano V, et al. Early changes in bioelectrical estimates of body composition in chronic kidney disease. J Am Soc Nephrol. 2006;17(5): 1481-1487. https://doi.org/10.1681/ASN.2005070756.

17 Georgiou E, Virvidakis K, Douskas G, et al. Body composition changes in chronic hemodialysis patients before and after hemodialysis as assessed by dual-energy x-ray absorptiometry. Metabolism. 1997;46(9):1059-1062. https://doi.org/10.1016/ S0026-0495(97)90278-X. 